\title{
Pencegahan Balita Gizi Kurang Melalui Penyuluhan Media Lembar Balik Gizi
}

\section{Prevention of Undernourished Children through Nutrition Education using Nutrition Flipchart}

\author{
Deni Era Nugrahaeni*
}

\begin{abstract}
ABSTRAK
Latar Belakang: Angka kejadian gizi kurang pada balita masih tinggi. Pengetahuan dan sikap ibu yang rendah mengenai penyedian menu seimbang untuk balita dapat berpengaruh terhadap pemberian makanan anak balita. Padahal status gizi balita merupakan salah satu indikator dalam pembangunan kesehatan di Indonesia.

Tujuan: Tujuan dari penelitian ini adalah untuk menganalisis perbedaan pengetahuan dan sikap ibu balita sebelum dan sesudah penyuluhan kesehatan dengan media lembar balik gizi. Hal tersebut untuk melihat bagaimana efektivitas penyuluhan kesehatan dengan media lembar balik terhadap pencegahan balita gizi kurang.

Metode: Penelitian ini bersifat observational dengan desain analitik dan cross-sectional karena penelitian dilakukan pada periode waktu tertentu. Populasi penelitian adalah sebanyak 81 ibu balita. Besar sampel ditentukan dengan rumus Lemeshow dan metode simple random sampling sehingga diperoleh 67 sampel. Data didapatkan melalui penilaian pengetahuan dan sikap sebelum dan sesudah penyuluhan kesehatan.

Hasil: Hasil uji statistika menunjukkan nilai $p$ value $(0,000)>\alpha(0,05)$. Hasil penilaian menunjukkan bahwa terdapat peningkatan tingkat pengetahuan dan sikap ibu balita. Ibu dengan tingkat pendidikan baik meningkat dari 16 ibu $(23,9 \%)$ naik menjadi 39 ibu (58,2\%). Ibu dengan sikap baik meningkat dari 14 ibu $(20,9 \%)$ menjadi 36 orang $(53,7 \%)$.

Kesimpulan: Terdapat perbedaan tingkat pengetahuan dan sikap ibu balita sebelum dan sesudah penyuluhan dengan media lembar balik gizi.
\end{abstract}

Kata kunci: gizi kurang, pencegahan, penyuluhan kesehatan, lembar balik 


\begin{abstract}
Background: The incidence of malnutrition in underfives is still high. The lack knowledge and attitude of mother about balance nutrient for child can affect the way child's feeding. Though, the nutritional status of underfives is one of the indicators in health development in Indonesia.

Objective: The aim of this study is to analyze the difference of knowledge and attitude on mother before and after health education with nutrition flipchart. This is to know how the effectiveness of helath education with flipchart on the prevention of underfives malnutrition.

Methods: This was an observational study with analitical and cross-sectional design because the study was conducted over a period of time. Study population were 81 mother. The sample size was determined by Lemeshow formula and simple random sampling and 67 mother were obtained. Data were collected by measuring knowledge and attitude before and after health education.

Results: Statistical result showed that $p$ values $(0.000)<\alpha(0.05)$. The result showed that was level of knowledge and attitude increased. Good knowledge level increased from 16 people (23.9\%) to 39 people (58.2\%). Good attitude inreased from 14 people (20.9\%) to 36 people (53.7\%).

Conclusion: There were difference on the result of mother's knowledge and attitude before and after health education with nutrition flipchart.
\end{abstract}

Keyword: malnutrition, prevention, health education, flipchart

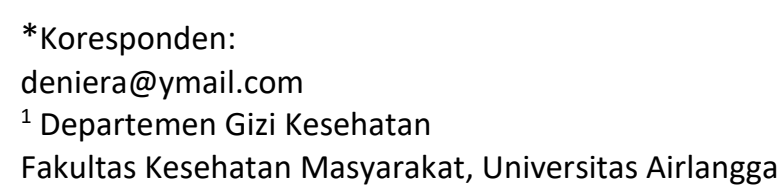

\section{PENDAHULUAN}

Pembangunan kesehatan di Indonesia dilakukan dengan menerapkan program Indonesia Sehat. Pembangunan kesehatan sendiri merupakan salah satu bagian terpenting dalam pembangunan nasional. Pembangunan kesehatan ini memiliki tujuan untuk mewujudkan derajat kesehatan penduduk Indonesia yang optimal dengan meningkatkan kesadaran, kemauan dan juga kemampuan dari masyarakat untuk menerapkan hidup sehat ${ }^{1}$.

Status gizi merupakan salah satu dari indikator keberhasilan dalam pembangunan kesehatan di Indonesia. Gizi sendiri termasuk masalah kesehatan masyarakat yang cukup serius di Indonesia. Salah satu permasalahan gizi yang masih menjadi tantangan berat bagi tenaga kesehatan adalah gizi kurang pada balita. Padahal balita merupakan bibit-bibit generasi masa depan bangsa. Sehingga,
Indonesia dituntut untuk maksimal dalam memperbaiki gizi balita tersebut ${ }^{2}$.

Usia balita sendiri sangat rawan mengalami gangguan kesehatan akibat dari status gizi yang kurang. Mengingat bahwa usia balita adalah awal dari pertumbuhan dan perkembangan anak. Dampak dari gizi yang kurang pada balita pun cukup beragam antara lain adalah meningkatnya risiko penyakit infeksi, menghambat pertumbuhan dan perkembangan anak, menyebabkan gangguan kesehatan saat usia remaja dan dewasa bahkan dapat meningkatkan risiko kematian anak ${ }^{2}$.

Gizi kurang pada balita juga dapat menyebabkan kelainan-kelainan fisik maupun mental $^{3}$. Perlunya perhatian yang lebih terjadinya gizi kurang pada masa emas balita ini diakibatkan karena dampaknya akan bersifat tidak dapat pulih atau irreversible. Lebih jauh lagi, kurangnya gizi pada balita mampu mengganggu perkembangan otaknya 
sehingga dapat memicu terganggunya gangguan mental ${ }^{4}$.

Senada dengan pendapat

Hovhannisyan, yang menyebutkan balita dengan gizi kurang dapat mengalami perkembangan kognitif yang buruk, pertumbuhan anak yang lambat, melemahnya kekebalan tubuh dan juga mampu meningkatkan morbiditas dan mortalitas pada balita $^{5}$. Menilik pada hasil Pemantauan Status Gizi Tahun 2016 di Indonesia diketahui bahwa sebanyak 3,1\% balita memiliki status gizi sangat kurus dan sebanyak $8,0 \%$ balita memiliki status gizi kurus. Status gizi balita di Provinsi Jawa Timur diketahui bahwa sebanyak 2,5\% balita memiliki status gizi sangat kurus dan balita yang memiliki status gizi kurus adalah sebanyak 7,2\% ${ }^{6}$.

Masalah gizi di Indonesia tidak hanya merupakan sindroma kemiskinan yang erat kaitannya dengan masalah ketahanan pangan pada tingkat rumah tangga. Masalah gizi juga menyangkut aspek pengetahuan, sikap dan juga perilaku yang kurang dalam menciptakan pola hidup yang sehat. Masih tingginya angka anak balita yang menderita gizi kurang di Indonesia menunjukkan bahwa kesadaran masyarakat mengenai gizi masih kurang ${ }^{5}$.

Kurangnya pengetahuan dan persepsi mengenai kebutuhan dan nilai pangan pada balita adalah hal yang umum dijumpai. Kurangnya pengetahuan ibu mengenai gizi balita akan berdampak pula pada pemenuhan nutrisi pada balita karena pengetahuan merupakan domain yang sangat penting dari terbentuknya perilaku seseorang, termasuk perilaku dalam pemenuhan gizi ${ }^{5}$. Perilaku seseorang diketahui akan lebih langgeng apabila didasari dengan adanya pengetahuan mengenai suatu hal tersebut ${ }^{7}$.

Adisasmito menjelaskan bahwa pengetahuan gizi keluarga dapat membantu menemukan berbagai alternatif solusi untuk pemecahan masalah gizi balita. Demikian halnya dengan sikap ibu balita, apabila sikap ibu kurang perhatian terhadap gizi balitanya maka dapat berakibat pada kurangnya pemenuhan gizi balita tersebut. Sehingga kejadian gizi kurang bahkan gizi buruk dapat terjadi ${ }^{8}$.
Adanya masalah tersebut maka muncul salah satu upaya dalam mencegah terjadinya gizi kurang pada balita yaitu dengan peningkatan pengetahuan, sikap dan juga perilaku dari ibu mengenai gizi balita. Pengetahuan yang kurang sehingga dapat merugikan kesehatan seyogyanya diubah ke arah yang menguntungkan kesehatan. Hal tersebut dikarenakan pengetahuan mampu mempengaruhi sikap yang akhirnya mampu mempengaruhi bagaimana seseorang berperilaku ${ }^{7}$.

Pengetahuan ibu mengenai pemenuhan gizi yang seimbang bagi balita merupakan hal yang penting. Pengetahuan tersebut mampu mengarahkan ibu untuk melakukan pemantauan pertumbuhan dan perkembangan balita dengan menyediakan makanan seimbang yang sesuai dengan kebutuhan gizi pada balita tersebut. Adanya pemenuhan gizi yang seimbang tersebut maka akan tercipta status gizi yang normal bagi balita dan angka balita gizi kurang akan menurun ${ }^{9}$.

Ibu dengan sumber informasi yang luas maka akan lebih banyak mempunyai pengetahuan mengenai gizi balita lebih banyak dibandingkan ibu dengan sumber informasi yang minim. Sehingga mereka dianggap lebih mampu untuk menangani masalah kesehatan terutama masalah gizi dikeluarganya dengan baik ${ }^{7}$.

Peningkatan pengetahuan, sikap dan perilaku tersebut dapat dilakukan salah satunya melalui pendidikan kesehatan. Seperti yang diungkapkan oleh Notoatmodjo, bahwa pendidikan kesehatan merupakan sarana informasi yang sangat intensif dan juga efektif dalam usaha untuk meningkatkan aspek kesehatan yang masih tertinggal di suatu tempat $^{10}$.

Pendidikan kesehatan sendiri dapat dilakukan dengan berbagai macam metode menyesuaikan sasaran yang akan diberikan pendidikan. Salah satu metode dalam pendidikan kesehatan adalah media lembar balik. Lembar balik atau flipchart adalah media yang berbentuk lembaran-lembaran menyerupai album atau kalender yang berisi gambar yang dibaliknya berisi mengenai informasi kesehatan mengenai gambar 
tersebut. Media ini cukup mudah digunakan dan dapat dimengerti dengan baik oleh para sasaran sehingga mampu meningkatkan pengetahuannya ${ }^{11}$.

Senada dengan penelitian Fitriani pada ibu balita gizi kurang di Puskesmas Pamulang Tanggerang Selatan. Diketahui bahwa pendidikan kesehatan dengan media lembar balik mampu meningkatkan pengetahuan ibu balita. Hal tersebut berdasarkan hasil penelitian yang menunjukkan bahwa terdapat peningkatan pengetahuan antara sebelum dan sesudah pemebrian pendidikan kesehatan dengan metode lembar balik ${ }^{12}$.

Penelitian ini bertujuan untuk mengetahui perbedaan pengetahuan dan sikap ibu balita mengenai gizi sebelum dan sesudah dilakukannya pendidikan kesehatan melalui media lembar balik. Dimana hal tersebut sebagai salah satu upaya pencegahan terjadinya gizi kurang pada balita.

\section{METODE}

Data yang dikumpulkan diperoleh dalam penelitian ini diperoleh tanpa adanya perlakuan pada subyek penelitian sehingga penelitian ini bersifat observasional. Variabel dalam penelitian ini adalah pengetahuan dan sikap dari ibu yang memiliki balita. Penelitian ini juga bersifat analitik apabila dilihat dari cara analisis data. Sedangkan menurut dimensi waktunya, penelitian ini termasuk ke dalam penelitian cross-sectional dimana variabel penelitian diperoleh dalam suatu periode tertentu.

Populasi penelitian ini adalah seluruh ibu yang memiliki balita di Wilayah Posyandu II Dusun Kecipik Desa Boteng yaitu sebanyak 81 ibu. Sampel dalam penelitian ini didapatkan dengan menggunakan rumus Lemeshow sehingga terdapat 67 sampel. Kriteria inklusi dalam penelitian ini adalah ibu yang memiliki balita dan bersedia menjadi responden penelitian. Sedangkan kriteria eksklusi adalah ibu balita yang tidak datang ke posyandu. Sampel didapatkan dengan menggunakan metode simple random sampling.

Lokasi penelitian dilakukan di Posyandu II Dusun Kecipik Desa Boteng Kecamatan
Menganti Kabupaten Gresik Jawa Timur. Waktu pengambilan data penelitian dilaksanakan pada Bulan Agustus 2017.

Variabel yang diteliti adalah pengetahuan dan sikap dari ibu hamil mengenai gizi balita. Pengumpulan data primer dilakukan dengan pengisian pretest dan posttest. Pretest diberikan sebelum dilakukannya pendidikan kesehatan dengan metode lembar balik. Posttest dilakukan 9 hari setelah dilakukannya pendidikan kesehatan. Jeda 9 hari tersebut disesuaikan dengan jadwal ibu balita tersebut untuk datang ke Posyandu. Selain itu, data mengenai karakteristik ibu balita juga dikumpulkan melalui kuesioner.

Kuesioner merupakan modifikasi dari kuesioner pengetahuan dan sikap ibu mengenai gizi balita. Kueioner telah dilakukan uji validitas dan reliabilitas yang menyatakan bahwa kuesioner telah valid dan reliabel untuk digunakan ${ }^{13}$.

Penyuluhan kesehatan dilakukan oleh peneliti. Lembar balik sebagai media penyuluhan kesehatan berisi mengenai pentingnya zat gizi bagi balita, kandungan zat gizi yang diperlukan oleh balita, makanan yang sesuai dalam pemenuhan gizi balita dan cara merencanakan menu gizi seimbang bagi balita. Penyuluhan kesehatan dilakukan dalam waktu 55 menit termasuk sesi diskusi dan tanya jawab.

Data pengetahuan dari ibu balita diperoleh berdasarkan diisinya pretest dan posttest dengan 15 item pertanyaan. Setiap jawaban yang benar akan dinilai 1 dan jawaban yang salah akan dinilai 0 . Skoring dari tingkat pengetahuan ibu balita tersebut dibagi menjadi 3 (tiga) kategori yaitu pengetahuan kurang, cukup dan baik.

Data sikap ibu balita diperoleh dari pretest dan posttest yang berisi 10 item pernyataan. Jawaban untuk setiap pernyataan adalah STS (Sangat Tidak Setuju), TS (Tidak Setuju), S (Setuju) dan SS (Sangat Setuju). Nilai skoring adalah 1-4 sesuai dengan jenis pertanyaannya yaitu unfavorable atau favorable.

Analisis dilakukan dalam bentuk tabel distribusi frekuensi meliputi karakteristik, pengetahuan dan sikap ibu balita. Selain itu 
digunakan grafik untuk melihat perubahan pengetahuan ibu balita sebelum dan sesudah dilakukan penyuluhan kesehatan. Data juga dianalisis dengan uji statistika Paired $t$ Test. Uji tersebut digunakan untuk mengetahui perbedaan tingkat pengetahuan dan sikap dari ibu balita mengenai gizi sebelum dan sesudah dilakukannya penyuluhan kesehatan dengan metode lembar balik.

\section{HASIL DAN PEMBAHASAN}

Desa Boteng terletak di Kecamatan Menganti Kabupaten Gresik, Jawa Timur. Desa Boteng memiliki 3 (tiga) dusun yaitu Dusun Boteng, Dusun Kecipik dan Dusun Masek. Desa dengan luas $1.573 .477 \mathrm{Ha}$ ini memiliki 2 (dua) posyandu. Posyandu I berpusat di Balai Desa Boteng yang mencakup 2 dusun yaitu Dusun Boteng dan Dusun Masek. Sedangkan Posyandu II berpusat di RT V Dusun Kecipik.

Di Desa Boteng terdapat masalah mengenai gizi balita. Masih terdapat balita dengan gizi kurang di desa tersebut. Ibu balita di desa tersebut kebanyakan tidak mengetahui pentingnya asupan gizi seimbang bagi balitanya sehingga hanya memberikan makanan seadanya. Hal tersebut juga disampaikan oleh petugas kesehatan, ibu balita terkadang tidak memanfaatkan pemberian makanan tambahan bagi balita yang disediakan di Posyandu Balita.

\section{Karakteristik Ibu Balita}

Karakteristik dari ibu balita di Posyandu

II Desa Boteng dalam penelitian ini adalah sebagai berikut: Berdasarkan Tabel 1 diketahui bahwa kelompok umur dengan jumlah ibu balita terbanyak yaitu 26 ibu $(38,8 \%)$ adalah rentang umur 17-25 tahun. Usia dapat mempengaruhi daya tangkap dan pola pikir ibu balita terhadap informasi yang diberikan padanya. Selain itu, usia merupakan salah satu faktor penentu tingkat pengetahuan, pengalaman dan motivasi dari ibu balita yang akan mempengaruhi bagaimana ibu tersebut berperilaku ${ }^{14}$.

Mubarak dan Chayatin menyebutkan bahwa dengan bertambahnya usia seseorang, maka akan muncullah perubahan-perubahan pada aspek baik fisik maupun psikologis.
Perubahan tersebut akan meningkatkan taraf pemikiran seseorang membuatnya semakin dewasa dan matanglbu balita yang berusia matang dianggap mau dan mampu menerima informasi baru untuk mengubah perilaku kesehatannya agar lebih baik. Selain itu, bertambahnya usia seseorang dapat meningkatkan pula pengalamannya sehingga pengetahuan yang dimilikinya akan cenderung lebih baik dibandingkan seseorang berusia lebih muda ${ }^{14}$.

Merujuk pada Tabel 1 menunjukkan bahwa sebagian besar ibu balita memiliki tingkat pendidikan dasar yaitu sebanyak 29 ibu $(43,3 \%)$. Pendidikan dasar adalah telah ditamatkannya Sekolah Dasar (SD) dan/atau Sekolah Menengah Pertama (SMP).

Pendidikan merupakan sebuah proses pengubahan sikap dan juga perilaku dari seseorang serta usaha untuk mendewasakan seseorang melalui upaya pengajaran dan juga pelatihan. Visi dari pendidikan adalah untuk mencerdaskan seseorang tersebut. Hingga kemudian pengetahuan, sikap dan perilaku seseorang juga ditentukan pula dengan tingkat pendidikan yang ia miliki?

Tabel 1. Distribusi Karakteristik Umum Ibu Balita di Posyandu II Dusun Kecipik Boteng, Menganti Gresik Tahun 2017

\begin{tabular}{lcc}
\hline \multicolumn{1}{c}{$\begin{array}{c}\text { Karakteristik } \\
\text { Umum }\end{array}$} & $\begin{array}{c}\text { Jumlah } \\
\text { (n) }\end{array}$ & $\begin{array}{c}\text { Persentase } \\
\text { (\%) }\end{array}$ \\
\hline Usia (Tahun) & 26 & 38,8 \\
$\begin{array}{l}17-25 \\
26-35\end{array}$ & 22 & 32,8 \\
$36-45$ & 19 & 28,4 \\
\hline \multicolumn{1}{c}{ Jumlah } & $\mathbf{6 7}$ & $\mathbf{1 0 0}$ \\
\hline Tingkat Pendidikan & & \\
Pendidikan Dasar & 29 & 43,3 \\
Pendidikan & 22 & 32,8 \\
Menengah & & \\
Pendidikan Tinggi & 16 & 23,9 \\
\hline \multicolumn{1}{c}{ Jumlah } & $\mathbf{6 7}$ & $\mathbf{1 0 0}$ \\
\hline Tingkat UMK & & \\
< UMK & 39 & 58,2 \\
$\geq$ UMK & 28 & 41,8 \\
\hline \multicolumn{1}{c}{ Jumlah } & $\mathbf{6 7}$ & $\mathbf{1 0 0}$ \\
\hline
\end{tabular}


Notoatmodjo menerangkan bahwa semakin tinggi tingkat pendidikan dari seseorang maka akan semakin mudah seorang tersebut menerima informasi yang diberikan padanya. Pendidikan diketahui sebagai salah satu kebutuhan dasar untuk mengembangkan diri seseorang. Sehingga semakin tinggi tingkat pendidikan seseorang, maka orang tersebut bukan hanya semakin mudah menerima informasi namun juga semakin mudah seseorang tersebut dalam mengimplementasikan informasi yang dimilikinya ${ }^{11}$.

Sama halnya dengan penelitian Putri, yang menyebutkan bahwa pendidikan ibu balita berhubungan dengan pemenuhan gizi bagi balita di Wilayah Kerja Puskesmas Nanggalo Padang. Tingkat pendidikan ibu balita yang relatif rendah kemudian dikaitkan pula dengan rendahnya sikap serta perilaku ibu dalam menangani pemenuhan gizi dan juga permasalah gizi kurang pada balitany ${ }^{14}$.

Tabel 1 menunjukkan bahwa sebanyak 39 ibu balita $(58,2 \%)$ memiliki pendapatan keluarga setiap bulannya < UMK Kabupaten Gresik 2016. UMK Kabupaten Gresik Tahun 2016 adalah sebesar Rp 3.293.506,25.

Tingkat pendapatan keluarga dapat menentukan kuantitas dan juga kualitas pangan yang disediakan untuk keluarga terutama untuk balita. Tingkat pendapatan keluarga dianggap sebagai penentu status gizi dari balita. Kemiskinan bahkan diketahui sebagai salah satu penyebab terjadinya gizi kurang pada balita. Keluarga dengan tingkat pendapatan rendah tidak mampu pula membeli makanan tambahan ${ }^{15}$. Tingkat pendapatan keluarga tidak berhubungan langsung dengan pengetahuan ibu balita namun dapat berhubungan dengan sikap dan perilaku ibu balita terhadap pemenuhan gizi.

\section{Pengetahuan dan Sikap Ibu Balita}

Sebelum penyuluhan kesehatan dilakukan, maka ibu balita diberikan pretest untuk mengetahui tingkat pengetahuan dan juga sikap ibu mengenai gizi balita. Setelah diberikan penyuluhan kesehatan, ibu balita juga diberikan posttest dengan pertanyaan yang sama dengan pretest. Hal itu dilakukan untuk mengetahui tingkat pengetahuan dan sikap ibu dan juga menjadi indikator keberhasilan penyuluhan kesehatan dengan media lembar balik gizi.

Pengetahuan ibu balita mengenai gizi yang baik maka dapat meminimalisir terjadinya gizi kurang pada balita. Sehingga pengetahuan ibu mengenai gizi balita sangat penting untuk ditingkatkan ${ }^{16}$.

Tabel 2 menunjukkan perbandingan kategori hasil pretest dan posttest pengetahuan dari ibu balita. Hasil dari pretest dan posttest ibu balita menunjukkan bahwa terdapat perbedaan pengetahuan ibu balita antara sebelum dan sesudah pemberian pendidikan kesehatan melalui penyuluhan kesehatan dengan media lembar balik. Perbedaan terlihat dari adanya peningkatan tingkat pengetahuan ibu balita.

Merujuk pada Tabel 2 diketahui bahwa sebelum penyuluhan sebagian besar ibu memiliki tingkat pengetahuan kurang yaitu sebanyak 32 ibu (47,8\%). Sedangkan sesudah penyuluhan meningkat, dimana ibu balita sebagian besar memiliki pengetahuan baik yaitu sebanyak 39 orang $(58,2 \%)$.

Tabel 2. Tingkat Pengetahuan Pretest dan Posttest Ibu Balita di Posyandu II Dusun Kecipik Boteng, Menganti Gresik Tahun 2017

\begin{tabular}{lllll}
\hline Kategori & Pretest & \multicolumn{3}{l}{ Posttest } \\
\cline { 2 - 5 } & $\mathrm{n}$ & $\%$ & $\mathrm{n}$ & $\%$ \\
\hline Kurang & 32 & 47,8 & 9 & 13,4 \\
Cukup & 19 & 28,4 & 19 & 28,4 \\
Baik & 16 & 23,9 & 39 & 58,2 \\
\hline Jumlah & $\mathbf{6 7}$ & $\mathbf{1 0 0}$ & $\mathbf{6 7}$ & $\mathbf{1 0 0}$ \\
\hline
\end{tabular}


40

20

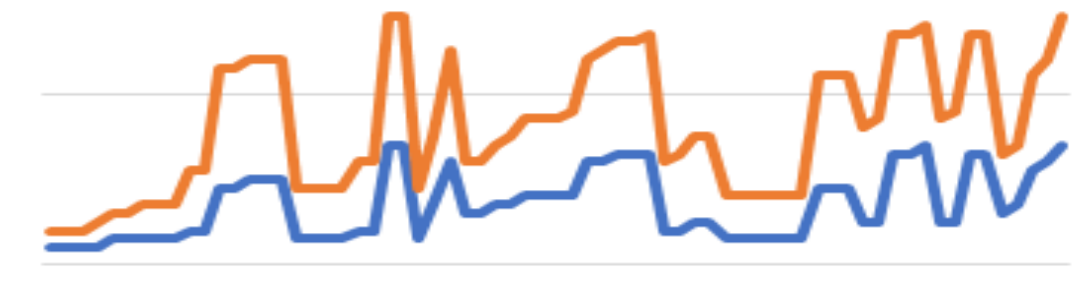

0

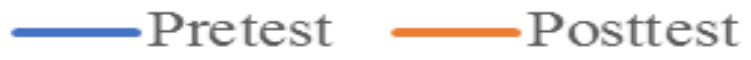

Gambar 1. Grafik Hasil Nilai Pretest dan Posttest Pengetahuan Ibu Balita

Senada dengan penelitian Arum, di Kecamatan Panti Kabupaten Jember. Diketahui bahwa terdapat perbedaan rerata skor pengetahuan ibu balita mengenai gizi anak sebelum dan sesudah dilakukannya penyuluhan kesehatan. Diketahui ibu balita menjadi lebih mengetahui bagaimana asuapan kebutuhan gizi yang seimbang bagi balitanya ${ }^{16}$.

Sama halnya dengan penelitian Rini bahwa terdapat peningkatan pengetahuan ibu balita di Dusun Jamprit Pundong Bantul Yogyakarta setelah diberikannya penyuluhan gizi balita. Hal tersebut ditunjukkan meningkatnya nilai jawaban yang benar dari pretest dan posttest yang diisi oleh ibu hamil $^{17}$.

Adanya peningkatan pengetahuan ibu balita tersebut dibuktikan pula dengan hasil uji statistika Paired t-Test. Hasil menunjukkan bahwa nilai $p$ value $(0,000)>\alpha(0,05)$. Artinya bahwa terdapat perbedaan yang signifikan antara hasil pretest dan posttest ibu balita di Dusun Kecipiki Desa Boteng.

Peningkatan pengetahuan setelah diberikannya penyuluhan kesehatan dengan media lembar balik juga digambarkan dengan jelas pada Gambar 1 di atas. Adanya penyuluhan kesehatan tersebut membuktikan pengaruhnya terhadap peningkatan pengetahuan ibu balita. Sehingga diketahui bahwa penyuluhan kesehatan berguna untuk meningkatkan pengetahuan.

Pengetahuan ibu balita yang meningkat antara lain adalah mengenai jenis-jenis gizi yang dibutuhkan oleh balita, makananmakanan apa saja yang dibutuhkan balita untuk memenuhi gizi seimbangnya, dampak dari kekurangan gizi, cara menentukan menu yang tepat bagi balita dan juga mengenai pentingnya pemenuhan zat gizi yang seimbang untuk balita.

Sebelum penyuluhan kesehatan, ibu balita tidak mengetahui mengenai kebutuhan gizi anak berdasarkan usianya, zat gizi apa saja yang dibutuhkan untuk pertumbuhan dan perkembangan balita, pola makan balita meliputi jenis bahan makanan, frekuensi makan, variasi menu, jumlah makanan dan sebagainya. Namun sesudah diberikan penyuluhan, ibu mengetahui hal-hal tersebut. Ibu balita juga menunjukkan beberapa ekspresi penyesalan saat baru mengetahui hal-hal penting mengenai gizi balita tersebut.

Hasil wawancara dengan ibu balita, mayoritas ibu balita memilih makanan untuk balita yang paling menarik pancaindera dan tidak memilih makanan sesuai dengan kebutuhan gizi balita. Hal tersebutlah mengapa kurangnya pengetahuan gizi ibu balita dapat menyebabkan berkurangnya pula kemampuan ibu dalam menerapkan informasi kesehatan yang benar dalam kehidupannya. Hal tersebut menyebabkan terjadinya kesenjangan antara informasi kesehatan yang baik dengan implementasi kesehatan yang tepat ${ }^{27}$.

Penyuluhan kesehatan dianggap suatu upaya untuk menjembatani adanya kesenjangan antara informasi kesehatan dan juga prakteknya. Apabila informasi kesehatan yang dimiliki telah benar maka kemudian akan memotivasi ibu balita untuk menerapkan informasi tersebut salah satunya adalah 
informasi mengenai gizi balita. Hal tersebut dapat mencegah balita mengalami kekurangan gizi di masa emas yaitu masa pertumbuhan dan perkembangannya ${ }^{11}$.

Semakin tinggi tingkat pengetahuan ibu balita maka akan semakin mudah ibu menerapkan informasi kesehatan tersebut. Dengan informasi yang benar mengenai kesehatan gizi, maka ibu balita akan menyediakan makanan bagi balita dengan tepat baik dari segi kuantitas maupun kualitas. Tersedianya makanan yang seimbang bagi balita maka angka kecukupan gizi balita dapat terpenuhi dengan baik ${ }^{10}$.

Selanjutnya pada Tabel 3 diketahui bahwa terdapat peningkatan sikap ibu balita mengenai gizi balitanya. Sebelum diberikan penyuluhan, ibu balita sebagian besar memiliki sikap yang cukup mengenai gizi balita yaitu sebanyak 28 ibu (41,8\%). Selain itu, juga masih terdapat 25 ibu balita $(37,3 \%)$ yang memiliki sikap kurang tentang gizi balita. Hal tersebut berubah sesudah diberikannya penyuluhan kesehatan dengan media lembar balik. Sebagian besar ibu balita memiliki sikap yang baik mengenai gizi balitanya yaitu sebanyak 36 ibu $(53,7 \%)$.

Hasil uji statistika dengan Paired $t$-test pun juga menunjukkan bahwa nilai $p$ value $(0,000)>\alpha(0,05)$. Sehingga dapat disimpulkan bahwa terdapat perbedaan yang signifikan antara sikap sikap ibu balita mengenai gizi balita sebelum dan sesudah dilakukannya penyuluhan kesehatan dengan media lembar balik.

Sikap ibu balita yang meningkat setelah dilakukannya penyuluhan kesehatan gizi ini sama dengan hasil penelitian Andriani pada ibu balita di Wilayah Kerja Puskesmas Puuwatu Kota Kendari. Diketahui bahwa terdapat perbedaan sikap ibu balita sebelum dan sesudah penyuluhan kesehatan mengenai pencegahan stunting dengan pemenuhan gizi yang tepat bagi balitanya ${ }^{18}$.

Senada pula dengan penelitian Syofia, di Kecamatan Medan Labuhan. Diketahui bahwa penyuluhan kesehatan dengan media lembar

Tabel 3. Sikap Pretest dan Posttest Ibu Balita di Posyandu II Dusun Kecipik Boteng, Menganti Gresik Tahun 2017

\begin{tabular}{ccccc}
\hline Kategori & \multicolumn{2}{c}{ Pretest } & \multicolumn{2}{c}{ Posttest } \\
\cline { 2 - 5 } & $\mathrm{n}$ & $\%$ & 15 & $\%$ \\
\hline Kurang & 25 & 37,3 & 16 & 22,4 \\
Cukup & 28 & 41,8 & 36 & 23,9 \\
Baik & 14 & 20,9 & $\mathbf{6 7}$ & $\mathbf{1 0 0}$ \\
\hline Jumlah & $\mathbf{6 7}$ & $\mathbf{1 0 0}$ & \\
\hline
\end{tabular}

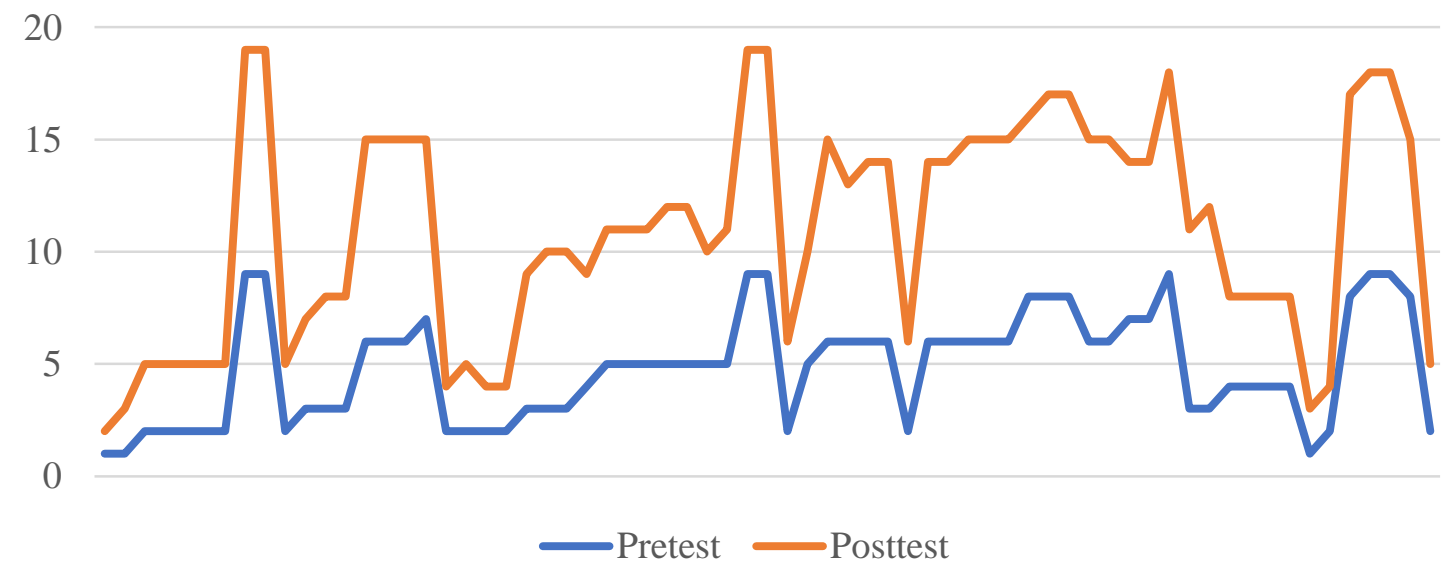

Gambar 2. Grafik Hasil Nilai Pretest dan Posttest Sikap Ibu Balita 
balik dapat meningkatkan sikap dari responden mengenai gizi beragam, seimbang dan aman. Ibu balita menjadi bersemangat untuk memenuhi keseimbangan balitanya ${ }^{19}$.

Apabila balita diberikan asupan gizi yang tidak sesuai dengan kebutuhannya maka akan menghambat laju pertumbuhan dan perkembangan dari balita tersebut. Asupan energi yang rendah akan mengakibatkan tubuh menggunakan lemak dan protein sebagai sumber energinya. Lemak dan protein tersebut kemudian tidak mampu melakukan fungsinya dan terjadilah gangguan pertumbuhan ${ }^{20}$.

Rendahnya sikap ibu balita mengenai gizi balitanya diakibatkan kurangnya pengetahuan ibu balita tersebut. Kurangnya informasi yang kemudian menjadi latarbelakang kurangnya pengetahuan dan rendahnya sikap ibu balita tersebut. Ibu balita cenderung tidak memperhatikan kebutuhan gizi anak sesuai dengan usianya. Karena salah satu faktor yang mendasari terbentuknya sikap seseorang adalah pengetahuan ${ }^{21}$.

Informasi kurang mengenai gizi balita tersebut tidak sesuai dengan perkembangan zaman saat ini. Saat ini adalah era globalisasi dimana akses mencari informasi kesehatan khususnya gizi balita sangat mudah ditemukan. Hal tersebut karena teknologi penyedia informasi kesehatan saat ini semakin mutakhir Perubahan sikap pada ibu balita dianggap dipengaruhi oleh seberapa jauh isi pesan atau rangsangan dari penyuluhan kesehatan diperhatikan, diterima dan dipahami dengan baik oleh ibu tersebut ${ }^{22}$.

Pengetahuan adalah komponen pembentukan sikap dan perilaku dari seseorang. Sehingga apabila pengetahuan dari ibu balita tidak memadai mengenai gizi balita. Maka akan berdampak pada sikap dan perilaku dari ibu balita dalam hal pemenuhan gizi balitanya. Hal tersebutlah yang menyebabkan angka balita yang mengalami gizi kurang masih banyak dan meningkat ${ }^{23}$.

Ibu balita yang memiliki pengetahuan yang baik akan menunjukkan sikap yang positif dan mempraktekkan dengan baik pemenuhan nutrisi bagi balitanya. Selain itu, ibu balita tersebut akan mampu untuk memotivasi ibu balita lainnya untuk turut memerhatikan pemenuhan gizi balitanya Notoatmodjo menjelaskan bahwa salah satu cara untuk merubah perilaku pada suatu individu atau kelompok adalah dengan dilakukannya pendidikan kesehatan. Dimana penyuluhan kesehatan merupakan salah satu caranya. Karena penyuluhan kesehatan dianggap mampu meningkatkan pengetahuan yang kemudian meningkatkan pula sikap dan perilaku positif terhadap kesehatan ${ }^{7}$.

Dengan adanya pengetahuan dan sikap yang baik ibu mengenai gizi balita. Ibu balita tersebut akan berusaha dengan maksimal untuk mencukupinya. Apabila terdapat berbagai masalah diluar dari pengetahuannya misalnya karena rendahnya ekonomi keluarga. Maka ibu dengan pengetahuan yang baik akan mencari alternatif solusi untuk mengatasi masalah tersebut. Contohnya ibu akan menanam bahan pangan dengan memanfaatkan pekarangan rumahnya. Dengan begitu penyuluhan kesehatan tidak hanya terpaku pada masalah kesehatan tersebut. Namun juga harus dikembangkan mengenai hal-hal yang kemungkinan dapat menghambat proses pemenuhan gizi balita tersebut.

Metode yang digunakan dalam penyuluhan pun juga beragam. Salah satunya adalah media lembar balik. Media ini dipilih karena metode yang lebih efektif dalam meningkatkan pengetahuan ibu balita. Diketahui dengan jelas bahwa media lembar balik lebih efektif meningkatkan pengetahuan dibandingkan dengan metode ceramah dengan power point ${ }^{24}$.

Selain itu, media lembar balik juga dapat diterima oleh ibu-ibu baik yang berpendidikan tinggi dan juga ibu berpendidikan rendah. Hal tersebut karena lembar balik berisikan gambar-gambar dengan isi pesan akan dijelaskan secara langsung oleh penyuluh. Mubarak tahun 2012 bahkan menyebutkan bahwa media ini cukup sering digunakan untuk penyuluhan terhadap ibu-ibu dan diketahui telah memberikan manfaat yang baik untuk peningkatan pengetahuan ibu tersebut ${ }^{25}$.

Keberhasilan penggunaan media lembar balik sebagai metode penyuluhan kesehatan juga sesuai dengan penelitian Purbowati di 
Puskesmas Kedaung Wetan Kota Tangerang. Diketahui bahwa terdapat perbedaan ang bermakna antara skor pengetahuan dan sikap sebelum dan sesudah mendapatkan penyuluhan kesehatan dengan media lembar balik gizi. Perbedaan tersebut dapat dilihat dari adanya kenaikan tingkat pengetahuan dan sikap responden ${ }^{26}$.

Senada pula dengan penelitian Mutiara bahwa penyuluhan kesehatan dengan media lembar balik dapat menyebabkan perubahan pada pengetahuan dan sikap responden. Penelitian yang dilakukan di Wilayah Kota Padang ini menyebutkan bahwa terjadi peningkatan pengetahuan sebesar $43 \%$ dan peningkatan sikap sebesar 9,5\%. Sehingga disimpulkan bahwa penggunaan media lembar balik dalam penyuluhan kesehatan pada penelitian tersebut adalah sangat efektif ${ }^{27}$.

Lembar balik efektif karena selain menyajikan gambar yang menarik juga dijelaskan oleh penyuluh yang kompeten. Responden akan cenderung memiliki kepercayaan mengenai materi penyuluhan yang disampaikan langsung oleh penyuluh yang memang sesuai dengan bidangnya. Media lembar balik yang merupakan media visual ini melibatkan indera penglihatan dalam proses penyampaian pesannya.

Hal tersebut sesuai dengan pendapat dari Notoatmodjo, bahwa penginderaan manusia mampu menghasilkan pengetahuan. Pengetahuan sendiri merupakan hasil berfikir seseorang terhadap suatu objek melalui indera mereka ${ }^{25}$.

Azizah, dalam penelitiannya menjelaskan bahwa indera penglihatan meruapakan indera yang paling banyak menyampaikan pengetahuan ke otak manusia. Diketahui sekitar 75\% sampai dengan $87 \%$ pengetahuan yang didapatkan oleh manusia disalurkan ke otak melalui indera penglihatan. Hanya sebanyak 13\% disampaikan melalui pendengaran dan $12 \%$ melalui indera lainnyan ${ }^{28}$.

Media visual memang dianggap mampu memberikan gambaran secara lebih jelas dan lebih menarik sebagai media penyuluhan kesehatan. Karena mampu menyampaikan pesan secara berbeda dan lebih menarik ${ }^{23}$. Media yang sesuai dengan sasaran maka akan memudahkan pesan yang disampaikan diterima dan dipahami oleh sasaran ${ }^{11}$.

Pemilihan media lembar balik gizi telah berhasil meningkatkan pengetahuan dan juga sikap dari ibu balita mengenai gizi balita. Hal tersebut terlihat dari meningkatnya pengetahuan dan sikap ibu balita. Dengan peningkatan pengetahuan maka akan memicu peningkatan sikap dan perilaku ibu dalam mengelola gizi yang seimbang bagi tumbuh dan kembang balita. Kemudian angka kejadian balita gizi kurang akan dapat ditekan. Dengan begitu, penyuluhan kesehatan dengan media lembar balik gizi dianggap sebagai salah satu pencegahan yang efektif terhadap terjadinya balita dengan gizi kurang.

\section{KESIMPULAN}

Hasil penilaian pretest dan posttest didapatkan bahwa terdapat peningkatan tingkat pengetahuan dan sikap dari ibu balita di Dusun Kecipik Desa Boteng, Menganti Gresik mengenai gizi seimbang bagi balita. Hal tersebut dibutkikan dengan hasil uji statistika yang menjelaskan bahwa terdapat perbedaan yang signifikan antara pengetahuan dan sikap ibu balita sebelum dan sesudah diberikan penyuluhan kesehatan.

Media yang digunakan dalam proses penyuluhan kesehatan juga berperan sangat penting terhadap keberhasilan penyuluhan. Media lembar balik yang digunakan mampu membuat ibu balita memperhatikan, menerima dan memahami pesan yang disampaikan dalam penyuluhan kesehatan.

Disarankan kepada ibu hamil untuk senantiasa meningkatkan pengetahuannya mengenai gizi balita. Hal tersebut dapat dilakukan dnegan melakukan konseling gizi dengan petugas kesehatan atau mencari informasi kesehatan secar amandiri melalui teknologi yang mutakhir saat ini. Selain itu, ibu balita harus rutin membawa balita untuk mengikuti Posyandu Balita sehingga status gizi balita sebagai faktor penentu tumbuh dan kembangnya dapat dimonitor secara berkala.

Disarankan pula bagi petugas kesehatan untuk terus melakukan pendidikan kesehatan kepada ibu balita. Selain itu, pendidikan mengenai faktor lain yang dapat menganggu 
kesehatan balita akibat gizi yang kurangjuga dapat diberikan kepada ibu balita.

\section{ACKNOWLEDGEMENT}

Peneliti mengucapkan terima kasih kepada Ketua PKK di Wilayah Posyandu II Dusun Kecipik Desa Boteng yang telah memberikan izin untuk dijadikan tempat penelitian sehingga penelitian ini dapat terlaksana serta Ibu yang memiliki balita di Wilayah Posyandu II Dusun Kecipik Desa Boteng telah meluangkan waktu membantu penelitian ini.

\section{REFERENSI}

1. Depkes RI. Petunjuk Teknis Standar Pelayanan Minimal (SPM) Penyelenggaraan Perbaikan Gizi Masyarakat. Dep. Kesehat. Republik Indones. Ditjen Bina Kesehat. Masy. Direktorat Gizi Masy. Jakarta (2004).

2. Arisman. Gizi Dalam Daur Kehidupan. (Direktorat Jenderal Pendidikan Tinggi Depdiknas, 2010).

3. Suhardjo. Perencanaan Pangan dan Gizi. (Bumi Aksara, 2010).

4. Marimbi, H. Tumbuh Kembang Status Gizi dan Imunisasi Dasar Pada Balita. (Nuha Medika, 2010).

5. Hovhannisyan, L., Demirchyan, A. \& Petrosyan, V. Estimated prevalence and predictors of undernutrition among children aged 5-17 months in Yerevan, Armenia. Public Health Nutr. 17, 10461053 (2014).

6. Kementerian Kesehatan. Hasil Pemantauan Status Gizi (PSG) 2016. Biro Komun. dan Pelayanan Masy. (2017).

7. Notoatmodjo, S. IImu perilaku kesehatan. Jakarta: Rineka Cipta 20-40 (2010).

8. Baliwati, Y. F., Khomsan, A. \& Dwiriani, C. M. Pengantar pangan dan gizi. (Penebar Swadaya, 2004).

9. Almatsier, S. Prinsip dasar ilmu gizi. (Gramedia Pustaka Utama, 2002).

10. Notoatmodjo, S. Promosi kesehatan Kesehatan teori dan aplikasi. (Rineka Cipta, 2010).
11. Fatmah. Gerakan sarapan sehat anak sekolah ( sarasehan ) untuk peningkatan pengetahuan ibu tentang sarapan sehat anak sekolah. J. Gizi Klin. Indones. 12, 12-19 (2015).

12. Fitriani, F. Pengaruh Penyuluhan Media Lembar Balik Gizi Terhadap Peningkatan Pengetahuan Ibu Balita Gizi Kurang di Puskesmas Pamulang, Tanggerang Selatan Tahun 2015. (2015).

13. Mubarak W, C. N. Ilmu Kesehatan Masyarakat Teori dan Aplikasi. (Salemba Medika, 2009).

14. Putri, R. F., Sulastri, D. \& Lestari, Y. Artikel Penelitian Faktor-Faktor yang Berhubungan dengan Status Gizi Anak Balita di Wilayah Kerja Puskesmas Nanggalo Padang. J. Kesehat. Andalas 4, 254-261 (2015).

15. Burhani, P. A., Oenzil, F. \& Revila, G. Hubungan Tingkat Pengetahuan Ibu dan Tingkat Ekonomo Keluarga Nelayan Dengan Status Gizi Balita di Kelurahan Air Tawar Barat Kota Padang. J. Kesehat. Andalas 5 No.3, 515-521 (2015).

16. Arum, P., Warsito, H. \& Ambar, E. Hubungan Pengetahuan Ibu dan Pola Asupan Gizi Terhadap Status Gizi Balita Sebelum dan Sesudah Dilakukan Penyuluhan Tentang Pola Asuhan Gizi di Kecamatan Panti Kabupaten Jember. J. Kesehat. 4, 14-32 (2016).

17. Rini, R. Pengaruh Penyuluhan Gizi Terhadap Pengetahuan Ibu Dalam Pemberian Menu Seimbang Pada Balita Di Dusun Jamprit Pundong Bantul Yogyakarta Tahun 2016. (UNIVERSITAS 'AISYIYAH YOGYAKARTA, 2016).

18. Andriani, W.O.S., Rezal, F., Nurzalmariah, W. O. . Perbedaan pengetahuan, sikap, dan motivasi ibu sesudah diberikan program mother smart grounding (msg) dalam pencegahan stunting di wilayah kerja puskesmas puuwatu kota kendari tahun 2017. J. Ilm. Mhs. Kesehat. Masy. 2, 1-9 (2017).

19. Syofia., Siagian, A. \& Nasution, E. Pengaruh Penyuluhan Makanan Bergizi Beragam Seimbang dan Aman Dengan Menggunakan Flash Card Dalam 
Meningkatkan Pengetahuan dan Sikap Anak Kelas 1-3 SD Islam Titi Berdikari Kecamatan Medan Labuhan Tahun 2014. Gizi, Kesehat. Reproduksi dan Epidemiol. 1, 1-6 (2014).

20. Baculu, E. P. H., M.Juffrie \& Helmyati, S. Faktor risiko gizi buruk pada balita di Kabupaten Donggala Provinsi Sulawesi Tengah. J. Gizi Dan Diet. Indones. 3, 51 (2015).

21. Azwar, S. Sikap Manusia, Teori dan Pengukurannya. (Pustaka Pelajar, 2008).

22. Efendi, F., M. Keperawatan Kesehatan Komunitas: Teori dan Praktik dalam Keperawatan. (Salemba Medika, 2009).

23. Sulistyoningsih, H. Gizi untuk Kesehatan Ibu dan Anak. (Graha Ilmu, 2011).

24. Nurhidayat, O. \&, Eram Tunggul P, B. W. Perbandingan Media Power Point Dengan Flip Chart Dalam Meningkatkan Pengetahuankesehatan Gigi Dan Mulut.
Unnes J. Public Heal. 1, 31-35 (2012).

25. Mubarak W.I. IImu Kesehatan Masyarakat Konsep dan Aplikasi Dalam kebidanan. (Salemba Medika, 2012).

26. Purbowati, N. Pengaruh Konseling Menggunakan Lembar Balik Dan Leaflet Terhadap Kepatuhan Ibu Hamil Mengkonsumsi Tablet Besi Di Kota Tangerang Tahun 2013. J. Tunas-Tunas Ris. Kesehat. 6, 143-147 (2016).

27. Notoatmodjo, S. Metodologi Penelitian Kesehatan. Jakarta:PT Rineka Cipta (2012).

28. Krisnana,I., Arief, Y,S., Azizah, D. . Media Ceramah dan Film Pendek Sebagai Upaya Pencegahan Penyakit Diare Berdasar Teori Health Promotif Model (HPM). Pediomaternal Nurse J. 3, 43-51 (2015). 